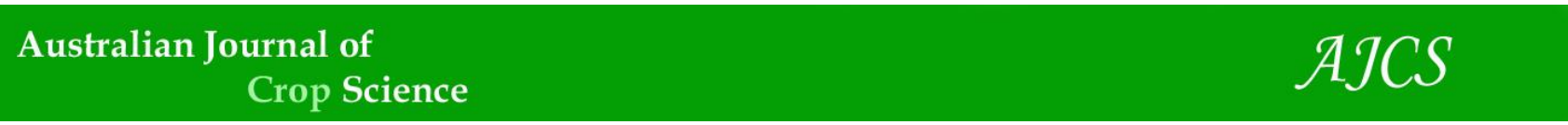

AJCS 15(02):260-270 (2021)

ISSN:1835-2707

doi: 10.21475/ajcs.21.15.02.p2958

\title{
Potential of two cover crops, signal grass and ruzi grass: suggested allelopathic effect on some important weeds
}

\author{
André Luís Gnaccarini Villela ${ }^{1}$, Rodrigo Martinelli ${ }^{2}$, Thiago Ferreira Zenatti ${ }^{2}$, Luiz Renato Rufino-Jr. ${ }^{2}$, \\ Patricia Andrea Monquero ${ }^{3}$, Patrícia Marluci da Conceição ${ }^{3}$, Fernando Alves de Azevedo*²
}

\author{
${ }^{1}$ Syngenta Brazil, Holambra (SP), Brazil \\ ${ }^{2}$ Instituto Agronômico (IAC), Centro de Citricultura "Sylvio Moreira", Cordeirópolis (SP), Brazil \\ ${ }^{3}$ Universidade Federal de São Carlos (UFSCar), Centro de Ciências Agrárias, Araras (SP), Brazil
}

\section{*Corresponding author: fernando@ccsm.br}

\begin{abstract}
There is evidence that signal (SG) and ruzi (RG) grass have an allelopathic effect on weeds. This study aim to evaluate this effects on difficult-to-control weeds: hairy beggarticks $(\mathrm{HB})$, benghal dayflower $(\mathrm{BD})$, horseweed $(\mathrm{H})$, sourgrass $(\mathrm{S})$ and tall windmill grass (TWG). The first experiment was installed in a completely randomized design with 2 donor species (SG and RG) $\times 4$ extract concentrations $\left(0,75,150\right.$ and $\left.225 \mathrm{mg} \mathrm{ml}^{-1}\right)$ in factorial scheme with four replicates. Weed germination percentage was evaluated in three-day intervals. In the second experiment, the weeds emerged in substrates previously cultivated with SG and RG, in completely randomised block design with four replicates. The emergence, shoot growth and root growth were evaluated. The results were as follows: (i) on horseweed $(\mathrm{H}), 84 \%$ germination inhibition by RG leaf extracts and $38 \%$ emergence inhibition by SG root exudates were observed; (ii) on benghal dayflower (BD), $84 \%$ germination inhibition by RG leaf extracts and $37 \%$ emergence inhibition and 4.3 times the SRL values than control by RG root exudates; (iii) on hairy beggarticks (HB) $52 \%$ germination inhibition by RG leaf extracts scored, while SG root exudates reduced $43 \%$ of the emergence, $24 \%$ shoots biomass accumulation and $11.3 \%$ root length; (iv) on sourgrass (S) $71 \%$ germination inhibition by both donor plants and $75 \%$ germination inhibition by RG leaf extracts were measured. Finally, on tall windmill grass (TWG) 69\% germination inhibition was observed upon using both donor plants. It can be concluded that foliar allelochemicals inhibit the germination of: BD $>\mathrm{S}>\mathrm{TWG}>\mathrm{H}>\mathrm{HB}$, while root exudate allelochemicals, inhibit the emergence and root development of all weeds.
\end{abstract}

Keywords: Urochloa; cover crops; ecological mowing; leaf extracts; integrated weed management; root exudates.

\section{Introduction}

Plants release a wide variety of secondary metabolites, especially through living and decomposing leaves and roots. Studies about the effect of these compounds on nearby plants is called allelopathy (Inderjit and Duke, 2003). Allelopathic compounds can be released through several processes, including but not limited to, leaching, root exudation, volatilisation, or decomposition of their residues, in both natural and agricultural systems (Ferguson and Rathinasabapathi, 2003). Allelochemicals are associated with inhibitory effects on germination and plant growth, which are of paramount importance to understanding plant interactions in natural environments and agroecosystems (Fritz et al., 2007).

Studies using alternative methods of weed control in cultivated or uncultivated systems, especially fusing secondary compounds produced by other plants, are important given the economic and ecological limitations of conventional weed control practices (Carvalho et al., 2012). Recently, some management strategies have proven successful in citrus such as using Urochloa species as a cover crop with a special ecological mower. This management deposits the mowed cover crop biomass from the inte-row to the planting line of the grove (i.e., the intra-row) as an insitu mulch. This management strategy, which is called ecological mowing, is an integrated and relatively sustainable weed management option that enhances weed control and fruit yield in citrus groves. The successes of ecological mowing in citrus groves indicate that signal grass (Urochloa decumbens) and ruzi grass ( $U$. ruziziensis) may have an allelopathic effect on weeds (Martinelli et al., 2017; Azevedo et al., 2020).

For perennial crops, cover crop/intercropping species management strategies should be exploited as they have possible advantages while avoiding competition with the primary crops. Therefore, methods to more effectively combat herbicide resistance in weeds such as using organic mulches, and integrated physical, chemical and biological methods of weed control, should be further investigated. Weeds can be controlled by the allelochemicals that are released as the biomass in organic mulch degrades, because even dead plant tissues can release allelochemicals. Incorporation of the allelochemicals into the soil can be accelerated by leaching from the decomposing biomass (Inderjit and Keating, 1999). 
The information derived from allelopathy experiments contributes to the understanding of the dynamics between plant species and expands the number of available options for alternative crop management and production strategies (Souza Filho et al., 2010). In Brazilian citrus groves, five weeds are the most frequent and most difficult to control: hairy beggarticks (Bidens pilosa), benghal dayflower (Commelina benghalensis), horseweed (Conyza canadensis), sourgrass (Digitaria insularis) and tall windmill grass (Chloris elata) (Alcántara-de La Cruz et al., 2020).

Benghal dayflower is considered one of the most important weed species in citrus groves. The conditions are highly favourable for development of benghal dayflower (BD), resulting in strong interference with the citrus crops, especially in young groves (Ronchi et al., 2002). Furthermore, benghal dayflower is tolerant of glyphosate, due to its ability to differentially absorb and translocate this herbicide (Monquero et al., 2004). Horseweed $(H)$ is another difficult-to-control weed. It is capable of producing more than 200,000 seeds per plant, and its seed bank can survive in no-till systems, compared to conventional cropping systems with soil tillage (Bhowmik and Bekech, 1993). In addition, horseweed has more than 60 cases of resistance to the most widely used herbicides in the world, including glyphosate and paraquat, and there have even been reports of multiple-herbicide resistance in this species (Heap, 2019). Sourgrass and tall windmill grass are two of the most difficult to control grasses in Brazilian citrus orchards, with cases of glyphosate resistance (Heap, 2019) and few effective herbicide options. Thus, it is fundamental to understand the relationships between weeds and Urochloa mulches to improve weed management strategies for citrus and other perennial crops. The present study hypothesised that signal grass and ruzi grass have allelopathic effects on five of the most important weeds in Brazilian citrus groves, namely, horseweed, benghal dayflower, hairy beggarticks, sourgrass and tall windmill grass through (i) foliar allelochemicals that affect the weeds' germination and (ii) root exudates that reduce weed germination/emergence and development. To evaluate the allelopathic effects of signal grass and ruzi grass on weeds, germination and emergence patterns, biomass accumulation and root development of some weeds were measured and analysed.

\section{Results and discussion}

\section{Response of weed germination to aqueous extracts of Urochloa spp.}

For the germination data as a function of time, there was an adjustment in the logistic model, in which a significant doseresponse relationship was observed for all species to Urochloa leaf extracts [Lack-of-fit $F$-test: lettuce, $(P=0.999)$, benghal dayflower $(P=0.958)$, horseweed (signal grass, $P=$ 0.999; ruzi grass, $P=0.999$ ), hairy beggarticks (signal grass, $P$ $=0.166$; ruzi grass, $P=0.170)$, sourgrass $(P=0.953)$ and tall windmill grass $(P=0.997)$ ] (Table 1 , Figure 1$)$. For all weeds, germination was negatively influenced by the donor plant leaf extracts (i.e., by allelochemicals from the signal grass and ruzi grass leaves).

For lettuce (indicator plant), germination was negatively influenced by the increase concentration of the donor plant leaf extracts regardless of the bioassay and Urochloa species. Lettuce germination was affected by leaf extracts from both Urochloa species at every concentration, with a maximum germination of $8 \%(d=0.08 \pm 0.02)$ (i.e., germination decreased 92\%) (Table 1; Figure 1).

Many studies demonstrate allelopathic effects on lettuce and its germination reductions. Exposing lettuce seeds to volatile substances from the pulverised leaves of some Brassicaceae species resulted in germination delays and reductions in overall growth (Oleszek, 1987). Aqueous extracts of Parthenium hysterophorus leaves and flowers also inhibited lettuce seed germination and seedling root and shoot growth, whereas roots exhibited more sensitivity to the allelopathic effects than shoots (Wakjira et al., 2005). Aqueous extracts of Cyperus rotundus basal bulbs inhibited lettuce germination (Muniz et al., 2007). In addition, leaf extracts of $U$. brizantha inhibited the growth of the roots and shoots of lettuce, garden cress (Lepidium sativum), timothy grass (Phleum pratense) and ryegrass (Lolium multiflorum) seedlings (Kato-Noguchi et al., 2014).

There are few studies demonstrating the allelopathic effect of signal grass on lettuce. One study has reported reduced germination rates in lettuce, Melinis minutiflora Beauv. and Phalaris canariensis L. from exposure to signal grass leaf extracts (Barbosa et al., 2008). The growth of the roots and shoots of lettuce, garden cress, timothy and ryegrass seedlings were inhibited (Kobayashi and Kato-Noguchi, 2015). The use of lettuce as an indicator plant has been confirmed, as it is the species that is most frequently used in germination bioassays and a robust gauge of the practical potential of a given allelochemical for weed control.

Among the weeds, both Urochloa species decreased the germination of benghal dayflower at every extract concentration, regardless of the bioassay and Urochloa species, with maximum germination decreases values of 72 to $84 \%$, respectively $\left(d=0.28 \pm 0.03\right.$ at $75 \mathrm{mg} \mathrm{ml}^{-1} ; d=$ $0.16 \pm 0.02$ at $150 \mathrm{mg} \mathrm{ml}^{-1}$ ) (Table 1; Figure 1). There are no previous reports of signal grass and ruzi grass leaf extracts inhibiting benghal dayflower germination. However, there are reports of the phytotoxic effects of extracts from Urochloa plantaginea, which contain pure organic acid solutions (aconitic acid and ferulic acid), associated with reductions in seed germination and root development. Additionally, aconitic acid stimulated the development of endophytic fungi (Fusarium solani), which was inversely related to seed germination, suggesting that fungal growth adversely affect germination (Voll et al., 2004).

Horseweed was sensitive to the leaf extracts from Urochloa species, particularly by ruzi grass. Increasing concentrations of both donor plant extracts decreased the maximum germination values of this weed regardless of the bioassay (Table 1; Figure 1). Ruzi grass extract at concentrations of $150 \mathrm{mg} \mathrm{ml}^{-1}$ decreased horseweed germination to $85 \%$ ( $d=$ $0.15 \pm 0.12$ ) and equally signal grass at concentrations of 225 $\mathrm{mg} \mathrm{ml}^{-1}$ to $84 \%(d=0.16 \pm 0.09)$. With increased of ruzi grass extract concentration, the germination rates of weed species further decreased by $87 \%(d=0.13 \pm 0.10)$ at $225 \mathrm{mg} \mathrm{ml}^{-1}$. This is the first report demonstrating that allelopathy can be used to augment integrated weed management and has the potential for suppression of difficult-to-control horseweed that has resistance/multiple resistance to herbicides. Furthermore, the time to $90 \%$ germination $\left(t_{90}\right)$ for horseweed differed between the Urochloa species, with ruzi grass extracts increasingly delayed germination by 19 days as the concentration increased $\left(t_{90}=25.95 \pm 5.97\right.$ days at 225 $\left.\mathrm{mg} \mathrm{ml}^{-1}\right)$, compared to the control $\left(t_{90}=6.76 \pm 3.5\right.$ days at 0 $\mathrm{mg} \mathrm{ml}^{-1}$ ) and to signal grass at any concentration (Table 1; Figure 1). 
This delay in germination and its effects on weed species can provide an important competitive advantage for the cultivated species and may be as important as germination inhibition (Belz et al., 2007). The germination delay make the seedlings to become more established when conditions are less favourable due to climate and/or competition. Furthermore, germination synchrony may provide a strategic time window for weed control.

For hairy beggarticks, regardless of the bioassays, the maximum concentrations of signal grass and ruzi grass extracts at $225 \mathrm{mg} \mathrm{ml}^{-1}$ reduced the maximum germination values to $69 \%(d=0.31 \pm 0.09)$ and $52 \%(d=0.48( \pm 0.19))$, respectively (Table 1 ; Figure 1 ). Even though, there was a high inhibition by signal grass. This indicates a certain tolerance by allelopathic effects from Urochloa on hairy beggarticks, when compared to the other weeds studied.

A recent study showed that the application of $0.5 \mathrm{mg} \mathrm{ml}^{-1}$ of ruzi grass extract affected hairy beggarticks in several ways: reduced seed germination, increased root growth with decreased root biomass, decreased mitochondrial respiration, as well as increased activity of the peroxidase and catalase enzymes (two oxidative stress enzymes). There were also morphological changes in the cells (Coelho et al., 2019). However, this study did consider osmotic potential as a factor. A study reported a certain level of tolerance of this weed by the need for relatively high levels of ruzi grass mulch to reduce the germination/emergence processes of hairy beggarticks, where a decrease in emergence was observed only with $8.0 \mathrm{t} \mathrm{ha}^{-1}$ of dry biomass of ruzi grass (Oliveira-Jr. et al., 2014). The results of the present study demonstrate the tolerance of hairy beggarticks to the effects of Urochloa, either physically through mulching and/or via allelopathic effects.

Another study with different plants demonstrated the potential of hairy beggarticks control, in which germination, growth and development were inhibited by parthenin, a natural constituent of Parthenium hysterophorus with phytotoxic and allelopathic properties (Batish et al., 2002). More recent study revealed that hairy beggarticks germination was completely inhibited when treated with Plantago lagopus and P. major leaf extracts (El-Gawad et al., 2015).

For sourgrass and tall windmill grass, regardless of the bioassays, germination was affected by leaf extracts from both Urochloa species at every concentration, with germination decrease of $71 \%(d=0.29 \pm 0.04)$ for sourgrass, and $69 \%(d=0.31 \pm 0.28)$ for tall windmill grass (Table 1 ; Figure 1). This is the first report of allelopathic effects for these two weeds. Only one study showed that soil cover with ruzi grass after soybean harvest reduced sourgrass potential for further infestation of the area (Gomes, 2016), demonstrating its potential for preventive control.

Altogether these data demonstrate that the susceptibility gradient was the same for ruzi grass and signal grass: lettuce $>$ benghal dayflower $>$ sourgrass $=$ tall windmill grass $=$ horseweed (with ruzi grass leaf extracts) > horseweed (with signal grass leaf extracts) > hairy beggarticks.

\section{Emergence and development of weeds in substrates previously cultivated with Urochloa spp.}

For the relative emergence data (of the bare soil control), there was an adjustment in the logistic model for all species [Lack-of-fit F-test: lettuce $(P=0.999)$, horseweed $(P=0.999)$; benghal dayflower (2017 bioassay: $P=0.999$; 2019 bioassay: $P=0.999)$; hairy beggarticks $(P=0.976)$; sourgrass $(P=0.999)$; tall windmill grass $(P=0.999)]$, where all the plants showed an increase in emergence over time, but with upper limits (parameter $d$ of the equation) and different times to emergence (parameter $t_{50}$ of the equation) (Table 2; Figures 2, 3 and 4).

The relative emergence of the lettuce was affected by the root exudates of the donor plants (i.e. the soils previously cultivated with the signal grass and ruzi grass), regardless of the bioassays, showing a decrease in emergence over time of $44 \%$ ( $d=0.56 \pm 0.07$ ) for signal grass root exudates, and only $17 \%(d=0.83 \pm 0.08)$ for ruzi grass root exudates (Table 2; Figure 2). We observed effect on the emergence speed, as the $t_{90}$ values for both signal grass (15.98 \pm 6.57 days) and ruzi grass (17.27 \pm 4.75 days) were higher than control (8.72 \pm 2.66 days).

The weed emergence responded negatively to the substrates treated with Urochloa exudates. For horseweed, regardless of the bioassays, signal grass reduced emergence values by $38 \%(d=0.62 \pm 0.05)$, and to a lesser degree, ruzi grass reduced emergence by $16 \%(d=0.84 \pm 0.06)$ (Table 2 ; Figure 2).

For benghal dayflower, there were differences between regression models in the two bioassays. A reduction in emergence was observed in the substrate previously cultivated with both ginal grass and ruzi grass (Table 2; Figure 3). In 2017 bioassay, only ruzi grass root exudates decreased emergence values to $35 \%$ ( $d=0.65 \pm 0.05)$, compared to the control. In 2019 bioassay, signal grass and ruzi grass root exudates decreased emergence to $31 \%$ ( $d=$ $0.69 \pm 0.08)$ and $37 \%(d=0.63 \pm 0.07)$, respectively. This difference between the years for the signal grass and benghal dayflower can be explained by the possible differences between the donor and receiver populations of both species. There was an observed effect on the emergence speed only in the 2019 bioassay, where a delay observed, and the $t_{90}$ value of signal grass (18.77 \pm 4.6 days) was higher than for both ruzi grass (12.51 \pm 5.2 days) and the control (10.8 \pm 2.44 days).

For hairy beggarticks, regardless of the bioassays, signal grass reduced emergence values by $43 \%(d=0.57 \pm 0.03)$ and, though to a lesser degree, ruzi grass reduced emergence by $33 \%(d=0.67 \pm 0.03$ ) (Table 2 ; Figure 4$)$. These results of hairy beggarticks, as well as for lettuce and horseweed, made it evident that Urochloa leaf extracts are more efficient at inhibiting germination than root exudates, particularly for signal grass, demonstrating that the strength of the allelopathic effect depends on the source of the allelochemicals.

For sourgrass, regardless of the bioassays, signal grass reduced emergence values by $27 \%(d=0.73 \pm 0.06)$ and, to a higher degree, ruzi grass reduced emergence by $75 \%(d=$ $0.25 \pm 0.05$ ) (Table 2; Figure 4). The same was observed for tall windmill grass, that regardless of the bioassays, signal grass reduced emergence values by $15 \%(d=0.85 \pm 0.06)$ and, to a higher degree, ruzi grass reduced emergence by $38 \%(d=0.62 \pm 0.06)$.

These results, combined with those from leaf extracts, demonstrate the high potential of ruzi grass for the preventive control of other grasses, something not expected because signal grass is the most widespread grass in Brazil, and consequently is known as the most aggressive weed. The shoot and root biomass of lettuce, benghal dayflower, hairy beggarticks, sourgrass and tall windmill grass were 
differently affected by the root exudates of the donor plants (shoots + roots) (Table 3; Figure 5). One exception was horseweed, which was the only weed species for which biomass accumulation was unaffected by the root exudates of Urochloa species.

Again, lettuce was the most affected by the donor plant root exudate treatments. The root exudates of signal grass and ruzi grass reduced lettuce shoot biomass per plant by 79 and $68 \%$, respectively, compared to the control, and the lettuce root biomass was reduced by 52 and $56 \%$ respectively for both donor species (Figure 5). It is noteworthy that even though the emerged lettuce plants escaped any allelopathic effects related to germination/emergence, their biomass accumulation was severely affected (Table 2; Figure 5). These results coupled with the results of Experiment I, in which lettuce had the highest germination inhibition values of the species tested, demonstrating that lettuce was the most sensitive to the allelopathic effects of the Urochloa, and an effective allelopathic indicator (Table 1; Figure 1).

The shoot biomass of benghal dayflower responded similarly to both donor plant root exudates, with increases of 89 and $178 \%$, for signal grass and ruzi grass respectively, compared to the control (Figure 5). This stimulation not only demonstrates the possible tolerance of this weed to both signal grass and ruzi grass, but also even indicate that it benefits from the root exudates, even though this species has its emergence levels somewhat affected (Figure 3). These results also offer a possible explanation for why this weed is one of the most frequent in citrus groves in São Paulo, Brazil, since Urochloa and signal grass are very common (Martinelli et al., 2017).

For hairy beggarticks, the signal grass and ruzi grass root exudates inhibited shoot biomass accumulation, with a reduction of 24 and $11 \%$, respectively, and inhibited root biomass accumulation by 11 and 27\%, respectively (Figure 5 ). The results indicate a certain tolerance by allelopathic effects from Urochloa on hairy beggarticks, because it was the species that had the lowest biomass decrease.

The shoot and root biomass of D. insularis and tall windmill grass responded similarly to ruzi grass root exudates, with a reduction of 13 and 7 times of the control for sourgrass shoot and root biomass, respectively, and with a reduction of 9 and 8 times the control for tall windmill grass shoot and root biomass, respectively (Figure 5). All weeds, with exception of benghal dayflower, showed treatment effects on specific root length (SRL). All weed species showed treatment effects except for sourgrass; and for root weight ratio (RWR). Only lettuce and benghal dayflower showed treatment effects (Table 3, Figure 6).

Horseweed root length was reduced by signal grass treatment by 2.5 times compared to control and ruzi grass. In horseweed, SRL (the root length per unit root weight) was affected by Urochloa, with a decrease of 3.9 times, compared to control (Table 3, Figure 6). In hairy beggarticks, signal grass and ruzi grass caused a $25 \%$ decrease in the root length and 1.3 times the SRL values. These results demonstrate that the low SRL values in horseweed and hairy beggarticks may be related to their high tolerance to the allelopathic effects of the signal grass and ruzi grass root exudates since low root biomass allocation for production of root length (i.e. high SRL values) is generally associated with high rates of root proliferation in disturbed soils (Eissenstat, 1991). To corroborate this high tolerance by the SRL value, the root biomass of horseweed did not differ from the control. In hairy beggarticks, signal grass and ruzi grass root exudates decreased shoot biomass accumulation by 11 and
$27 \%$, respectively (Figure 5). This highlights the use of SRL as an indicator of allelopathic effects on roots for some species. The SRL was already shown to be indicative of the inhibitory effects of root exudates in a study where the germination and growth of bermudagrass [Cynodon dactylon (L.) Pers.] was negatively affected by perennial ryegrass (Lolium perenne L.) root extracts (McCarty et al., 2010).

There was an increase in SRL that was unique to lettuce, benghal dayflower and tall windmill grass, with increases of 1.8 times (for signal grass) the control value for lettuce, 2.5 times (for signal grass) and 4.3 times (for ruzi grass) the control value for benghal dayflower, with increases of 2.0 times (for ruzi grass) for tall windmill grass (Figure 6). The opposite pattern that was occurred for low SRL values may be related to their low tolerance to the allelopathic effects of the signal grass and ruzi grass root exudates.

Interestingly, another opposite pattern was occurred in the benghal dayflower RWR (i.e., the relative biomass allocation to the roots), where ruzi grass caused half of the biomass to be allocated to the roots compared to the control (Figure 6). In some cases, a lower allocation of biomass to the roots (RWR) can be compensated by a high SRL value (Aerts et al., 1991). However, this compensatory pattern was only observed in benghal dayflower. In addition, the ruzi grass treatment was the only one that reduced germination and/or emergence in benghal dayflower in the two bioassays (Table 2; Figure 3), which corroborates the negative allelopathic effect among these species. For lettuce, the RWR was 1.8 times higher for signal grass and ruzi grass than the control, which may explain the severe decrease in the biomass accumulation values observed for this species. Generally, increases in RWR values occur in less favourable environments. For example, a decreased nitrogen supply proportionately may increase biomass allocation to the roots relative to the shoots (RWR) of Brachypodium pinnatum and Dactylis glomerate. The same was observed for the phosphorus supply, but at a lower intensity (Ryser and Lambers, 1995). Similarly, an efficient nitrification inhibitor known as brachialactone, was found in the root exudates of Urochloa humidicola (Rendle) Schweick. The process of suppression of soil nitrification by the release of root inhibitors is known as biological nitrification inhibition (BNI) (Subbarao et al., 2009) and may explain the allelopathic effect of the root exudates on the two tested species, since they are of the same genus. Additionally, the high RWR values observed for lettuce show that the root exudates of the donor plants made unfavourable growing conditions, as detailed above. Sourgrass and tall windmill grass root length was affected by ruzi grass treatment with 13 and 9 times decreases, compared to control, respectively (Figure 6). This species had the most affected shoot and root biomass accumulation, with more significant losses than the indicator plant, in this case, lettuce. These results also corroborate to demonstrate the high potential of ruzi grass for the preventive control of other grasses with one of the lowest germinations of plant extracts and for root exudates (Figures 1 and 4). Even though, the presence or absence of an allelopathic substance was not directly assessed in this study. The allelopathic effects were detected and more realistically demonstrated which would be observed in the field. The allelopathic effects of Urochloa species in Brazil emerged from reports of signal grass among citrus trees, in which lemon tree (Citrus limon) reduced heights were noted for seedlings that were planted in old signal grass pastures (Souza et al., 1997). 
Table 1. Parameters of the equations and $t_{90}$ values obtained through the logistic model for the relative emergence (to the control) of the lettuce, horseweed, Benghal dayflower, hairy beggarticks, sourgrass and tall windmill grass under the Urochloa leaf extracts (signal grass - SG and ruzi grass - RG) as well as the relative emergence of horseweed and hairy beggarticks under the concentrations of Urochloa leaf extracts and its concentration values. The $t_{50}$ and $t_{90}$ values represent the time required for 50 and $90 \%$ of the germination. \pm represents the standard error of the mean.

\begin{tabular}{|c|c|c|c|c|c|c|}
\hline \multirow{2}{*}{ Species } & \multirow{2}{*}{$\begin{array}{l}\text { Leaf } \\
\text { extracts }\end{array}$} & \multirow{2}{*}{$\begin{array}{l}\text { Concentration } \\
\left(\mathrm{mg} \mathrm{ml}^{-1}\right)\end{array}$} & \multicolumn{3}{|c|}{ Equation parameters } & \multirow{2}{*}{$t_{90}$} \\
\hline & & & $d$ & $b$ & $t_{50}$ & \\
\hline \multirow[t]{4}{*}{ Lettuce } & SG/RG & 0 & $1.00( \pm 0.01)$ & $-6.36( \pm 0.30)$ & $10.1( \pm 5.36)$ & $10.5( \pm 6.90)$ \\
\hline & & 75 & $0.16( \pm 0.01)$ & $-4.19( \pm 0.37)$ & $11.6( \pm 3.66)$ & $12.1( \pm 1.01)$ \\
\hline & & 150 & $0.28( \pm 0.01)$ & $-7.88( \pm 1.60)$ & $9.93( \pm 1.88)$ & $10.2( \pm 2.41)$ \\
\hline & & 225 & $0.07( \pm 0.01)$ & $-2.88( \pm 6.06)$ & $10.6( \pm 3.18)$ & $11.3( \pm 3.63)$ \\
\hline \multirow[t]{4}{*}{ Benghal dayflower } & $\mathrm{SG} / \mathrm{RG}$ & 0 & $1.00( \pm 0.03)$ & $-0.79( \pm 0.11)$ & $5.60( \pm 0.02)$ & $8.38( \pm 0.44)$ \\
\hline & & 75 & $0.28( \pm 0.03)$ & $-1.03( \pm 0.81)$ & $5.81( \pm 0.59)$ & $7.95( \pm 1.71)$ \\
\hline & & 150 & $0.16( \pm 0.02)$ & $-0.94( \pm 0.98)$ & $5.49( \pm 1.14)$ & $7.83( \pm 2.50)$ \\
\hline & & 225 & $0.20( \pm 0.03)$ & $-0.83( \pm 0.70)$ & $5.88( \pm 0.95)$ & $8.52( \pm 2.36)$ \\
\hline \multirow[t]{8}{*}{ Horseweed } & SG & 0 & $0.99( \pm 0.09)$ & $-2.99( \pm 0.23)$ & $6.00( \pm 0.19)$ & $6.73( \pm 5.76)$ \\
\hline & & 75 & $0.64( \pm 0.09)$ & $-4.07( \pm 0.22)$ & $7.33( \pm 7.86)$ & $7.86( \pm 8.95)$ \\
\hline & & 150 & $0.27( \pm 0.11)$ & $-2.85( \pm 0.19)$ & $7.66( \pm 9.91)$ & $8.42( \pm 9.98)$ \\
\hline & & 225 & $0.16( \pm 0.09)$ & $-13.1( \pm 2.20)$ & $7.20( \pm 1.10)$ & $7.37( \pm 10.70)$ \\
\hline & RG & 0 & $1.00( \pm 0.11)$ & $-2.89( \pm 2.55)$ & $6.00( \pm 0.25)$ & $6.76( \pm 3.50)$ \\
\hline & & 75 & $0.70( \pm 0.07)$ & $-3.89( \pm 2.12)$ & $7.07( \pm 2.26)$ & $8.27( \pm 2.17)$ \\
\hline & & 150 & $0.15( \pm 0.12)$ & $-1.80( \pm 7.61)$ & $7.50( \pm 6.45)$ & $8.73( \pm 8.51)$ \\
\hline & & 225 & $0.13( \pm 0.10)$ & $-0.28( \pm 2.16)$ & $18.13( \pm 6.90)$ & $25.95( \pm 5.47)$ \\
\hline \multirow[t]{8}{*}{ Hairy beggarticks } & SG & 0 & $1.00( \pm 0.57)$ & $-2.01( \pm 0.93)$ & $4.19( \pm 2.10)$ & $25.25( \pm 2.32)$ \\
\hline & & 75 & $0.97( \pm 0.31)$ & $-2.46( \pm 1.28)$ & $6.74( \pm 2.58)$ & $16.47( \pm 3.90)$ \\
\hline & & 150 & $0.41( \pm 0.13)$ & $-22.1( \pm 4.32)$ & $9.38( \pm 7.26)$ & $10.37( \pm 9.74)$ \\
\hline & & 225 & $0.31( \pm 0.09)$ & $-23.9( \pm 2,94)$ & $9.55( \pm 7.15)$ & $10.48( \pm 9.68)$ \\
\hline & RG & 0 & $1.00( \pm 0.6)$ & $-1.98( \pm 0.98)$ & $8.39( \pm 1.45)$ & $25.5( \pm 2.69)$ \\
\hline & & 75 & $1.27( \pm 0.09)$ & $-2.06( \pm 1.11)$ & $10.12( \pm 6.98)$ & $29.55( \pm 3.83)$ \\
\hline & & 150 & $0.62( \pm 0.10)$ & $-22.93( \pm 10.6)$ & $9.63( \pm 3.08)$ & $10.6( \pm 8.05)$ \\
\hline & & 225 & $0.71( \pm 0.11)$ & $-2.43( \pm 3.60)$ & $12.1( \pm 16.7)$ & $29.9( \pm 7.39)$ \\
\hline Sourgrass & SG/RG & - & $0.29( \pm 0.04)$ & $-1.47( \pm 1.53)$ & $4.18( \pm 1.39)$ & $5.68( \pm 2.61)$ \\
\hline Tall windmill grass & $\mathrm{SG} / \mathrm{RG}$ & - & $0.31( \pm 0.28)$ & $-1.47( \pm 4.52)$ & $2.89( \pm 3.53)$ & $12.9( \pm 6.92)$ \\
\hline
\end{tabular}

Table 2. Parameters of the equations and $t_{90}$ values obtained through the logistic model obtained for the relative emergence (to the control) of the lettuce, horseweed, Benghal dayflower, hairy beggarticks, sourgrass and tall windmill grass as a function of previously cultivated soils with Urochloa (signal grass-SG and ruzi grass-RG) and without exudate (control). The values of $t_{50}$ and $t_{90}$ represent the time required for 50 and $90 \%$ of the emergence. \pm represents the standard error of the mean.

\begin{tabular}{|c|c|c|c|c|c|c|}
\hline \multirow{2}{*}{ Species } & \multirow{2}{*}{ Year } & \multirow{2}{*}{ Treatments } & \multicolumn{3}{|c|}{ Equation parameters } & \multirow{2}{*}{$t_{90}$} \\
\hline & & & $d$ & $b$ & $t_{50}$ & \\
\hline \multirow[t]{3}{*}{ Lettuce } & & Control & $0.97( \pm 0.05)$ & $-0.46( \pm 0.20)$ & $4.00( \pm 0.09)$ & $8.72( \pm 2.66)$ \\
\hline & & SG & $0.56( \pm 0.07)$ & $-0.25( \pm 0.14)$ & $7.18( \pm 2.47)$ & $15.98( \pm 6.57)$ \\
\hline & & RG & $0.83( \pm 0.08)$ & $-0.22( \pm 0.08)$ & $7.22( \pm 1.82)$ & $17.27( \pm 4.75)$ \\
\hline \multirow[t]{3}{*}{ Horseweed } & & Control & $0.99( \pm 0.06)$ & $-0.31( \pm 0.07)$ & $12.80( \pm 0.09)$ & $19.92( \pm 2.12)$ \\
\hline & & SG & $0.62( \pm 0.05)$ & $-0.33( \pm 0.12)$ & $10.84( \pm 1.33)$ & $17.45( \pm 2.87)$ \\
\hline & & RG & $0.84( \pm 0.06)$ & $-0.29( \pm 0.08)$ & $13.34( \pm 1.16)$ & $20.98( \pm 2.74)$ \\
\hline \multirow[t]{6}{*}{ Benghal dayflower } & 2017 & Control & $0.96( \pm 0.05)$ & $-2.68( \pm 7.00)$ & $23.72( \pm 2.09)$ & $24.54( \pm 2.00)$ \\
\hline & & SG & $0.99( \pm 0.05)$ & $-4.30( \pm 18.9)$ & $23.54( \pm 2.02)$ & $24.04( \pm 0.29)$ \\
\hline & & RG & $0.65( \pm 0.05)$ & $-2.99( \pm 4.95)$ & $22.69( \pm 2.29)$ & $23.42( \pm 2.02)$ \\
\hline & 2019 & Control & $0.95( \pm 0.06)$ & $-0.55( \pm 0.26)$ & $6.80( \pm 0.95)$ & $10.77( \pm 2.44)$ \\
\hline & & SG & $0.69( \pm 0.08)$ & $-0.29( \pm 12.8)$ & $11.11( \pm 2.01)$ & $18.77( \pm 4.59)$ \\
\hline & & RG & $0.63( \pm 0.07)$ & $-0.49( \pm 4.38)$ & $8.00( \pm 1.70)$ & $12.51( \pm 5.22)$ \\
\hline \multirow[t]{3}{*}{ Hairy beggarticks } & & Control & $0.94( \pm 0.02)$ & $-0.79( \pm 0.25)$ & $3.14( \pm 0.37)$ & $5.93( \pm 1.08)$ \\
\hline & & SG & $0.57( \pm 0.03)$ & $-0.54( \pm 0.21)$ & $3.96( \pm 0.77)$ & $8.00( \pm 1.99)$ \\
\hline & & RG & $0.67( \pm 0.03)$ & $-0.43( \pm .14)$ & $4.73( \pm 0.77)$ & $9.82( \pm 2.17)$ \\
\hline \multirow[t]{3}{*}{ Sourgrass } & & Control & $0.95( \pm 0.04)$ & $-1.44( \pm 0.98)$ & $5.11( \pm 0.65)$ & $6.63( \pm 0.8)$ \\
\hline & & SG & $0.73( \pm 0.06)$ & $-0.41( \pm 0.21)$ & $7.16(1.34 \pm)$ & $12.5( \pm 3.6)$ \\
\hline & & RG & $0.25( \pm 0.05)$ & $-0.67( \pm 1.21)$ & $5.88( \pm 2.59)$ & $9.15( \pm 7.25)$ \\
\hline \multirow[t]{3}{*}{ Tall windmill grass } & & Control & $0.92( \pm 0.04)$ & $-0.33( \pm 0.07)$ & $7.71( \pm 0.78)$ & $14.51( \pm 1.93)$ \\
\hline & & SG & $0.85( \pm 0.06)$ & $-0.23( \pm 0.05)$ & $11.5( \pm 1.35)$ & $21.05( \pm 3.17)$ \\
\hline & & RG & $0.62( \pm 0.06)$ & $-0.27( \pm 0.09)$ & $13.76( \pm 1.65)$ & $21.81( \pm 3.7)$ \\
\hline
\end{tabular}




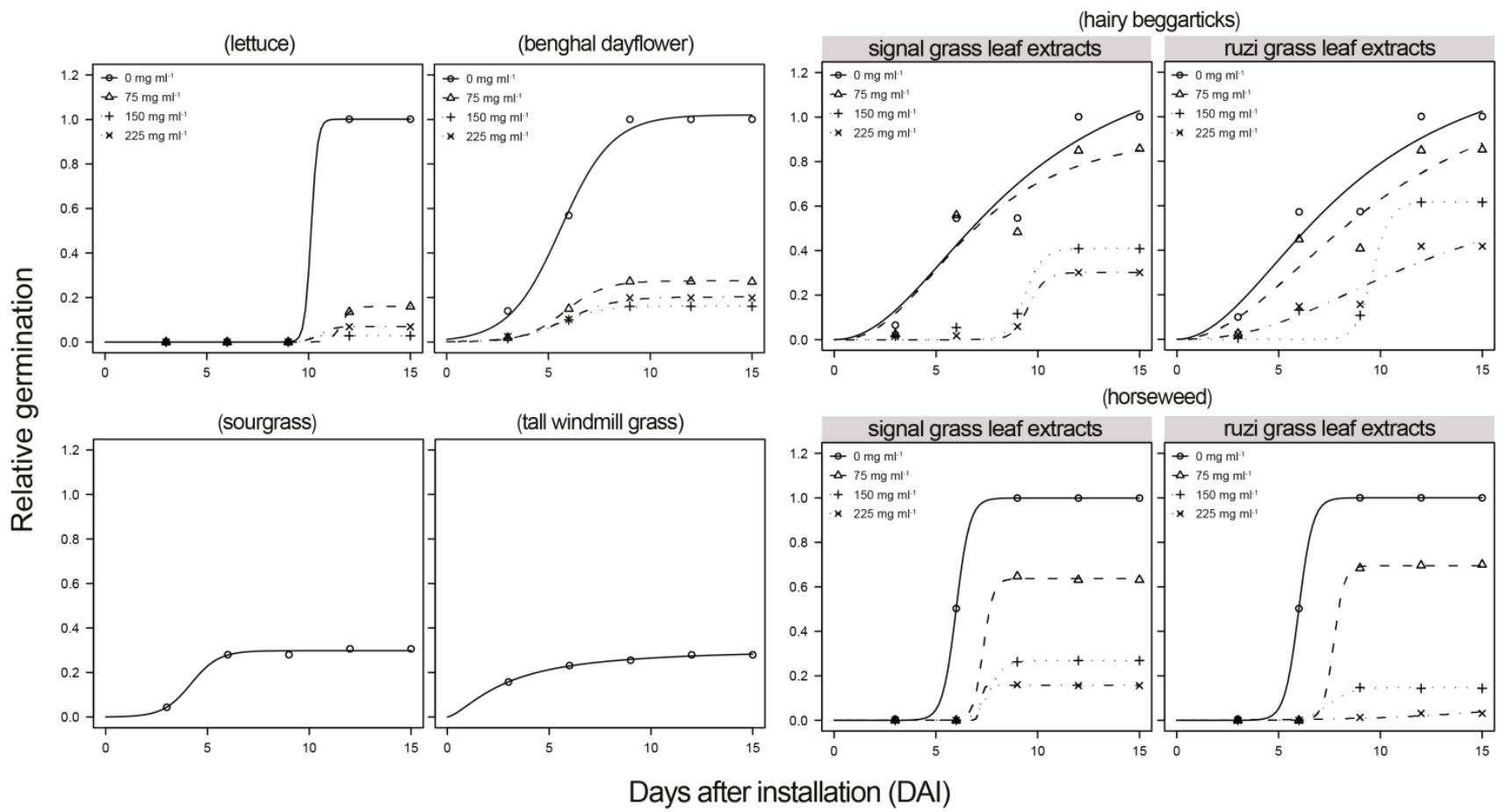

Fig 1. Relative germination (of the control) of lettuce, benghal dayflower, horseweed, hairy beggarticks, sourgrass and tall windmill grass on Urochloa leaf extracts (signal grass and ruzi grass) and its concentration values as a function of time (DAl: days after installation). The relative germination is represented by the ratio between treatments germination and the control. The parameters of the equations are found in Table $1 .{ }^{*}$ For sourgrass and tall windmill grass, all concentrations obtained the same result in the regression model, so only one curve is presented representing the average concentration of 75, 150 and $225 \mathrm{mg} \mathrm{ml}^{-1}$.

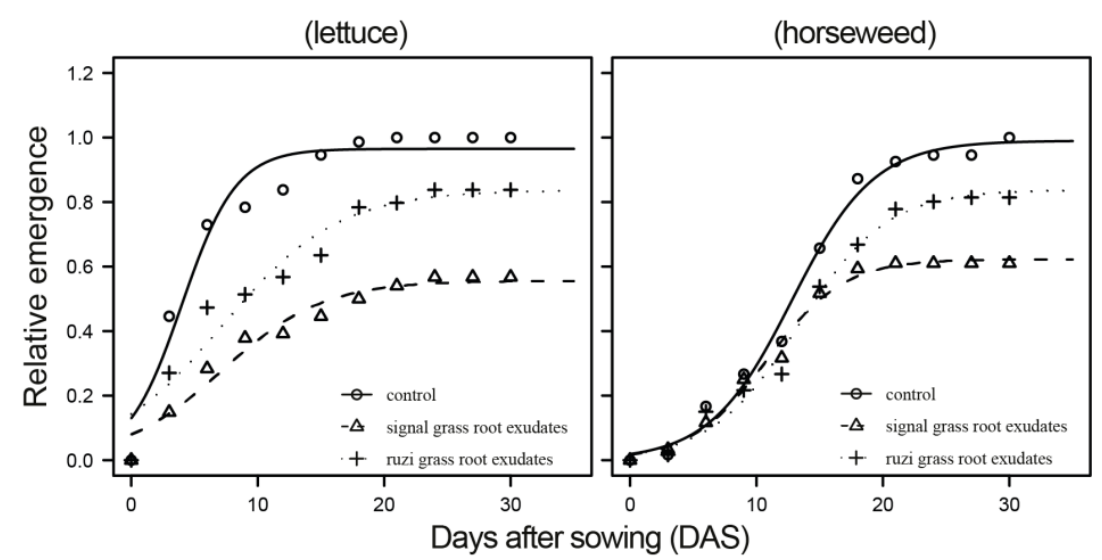

Fig 2. Relative emergence on different evaluation dates (DAS: days after sowing) of lettuce and horseweed, as a function of previously cultivated soils with Urochloa (signal grass and ruzi grass) and control (without root exudates). The relative emergence is represented by the ratio between the emergence treatments emergence and the control. The parameters of the equations are in Table 2.

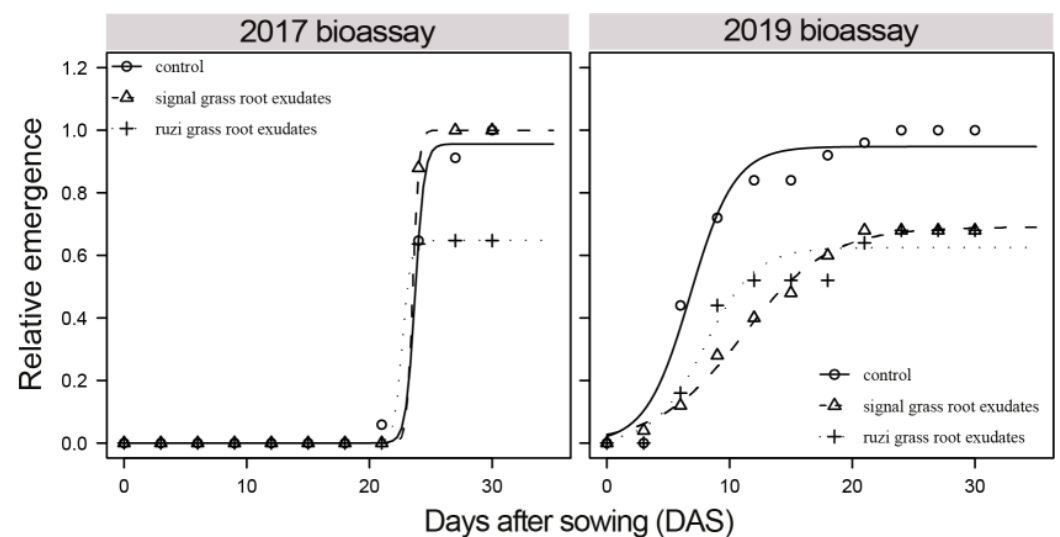

Fig 3. Relative emergence on different evaluation dates (DAS: days after sowing) of benghal dayflower as a function of previously cultivated soils with Urochloa (signal grass and ruzi grass) and control (without root exudates) in the 2017 and 2019 bioassays. The relative emergence is represented by the ratio between emergence treatments and the control. The parameters of the equations are in Table 2. 
Table 3. Summary of analysis of variance (ANOVA) with degrees of freedom (df) of treatments and $\operatorname{Pr}>F$ for dry mass (DM) data of the shoots, roots and total (roots + shoots), root length, specific root length (SRL) and root weight ratio (RWR) of lettuce (Lactuca sativa), Conyza canadensis, Commelina benghalensis, Bidens pilosa, Digitaria insularis and Chloris elata as a function of previously cultivated soils with Urochloa. *: P<0.05**: $P<0.01 ; * *$ : $P<0.001$.

\begin{tabular}{|c|c|c|c|c|c|c|}
\hline Source & & Shoots DM & Roots DM & Root Length & SRL & RWR \\
\hline Species & $\mathrm{df}$ & $\operatorname{Pr}>F$ & & & & \\
\hline \multicolumn{7}{|l|}{ lettuce } \\
\hline Bioassay $(A)$ & 1 & $0.490^{\mathrm{ns}}$ & $0.390^{\mathrm{ns}}$ & $0.703^{\mathrm{ns}}$ & $0.368^{\mathrm{ns}}$ & $0.404^{\mathrm{ns}}$ \\
\hline Root exsudates (B) & 2 & $<0.001 * * *$ & $<0.001^{* * *}$ & $0.049 *$ & $0.031^{*}$ & $0.024 *$ \\
\hline A.B & 2 & $0.451^{\mathrm{ns}}$ & $0.223^{\mathrm{ns}}$ & $0.120^{\mathrm{ns}}$ & $0.116^{\mathrm{ns}}$ & $0.19^{\mathrm{ns}}$ \\
\hline \multicolumn{7}{|l|}{ C. canadensis } \\
\hline Bioassay $(A)$ & 1 & $0.310^{\mathrm{ns}}$ & $0.335^{\mathrm{ns}}$ & $0.257^{\mathrm{ns}}$ & $0.180^{\mathrm{ns}}$ & $0.253^{\text {ns }}$ \\
\hline Root exsudates (B) & 2 & $0.455^{\mathrm{ns}}$ & $0.339^{\mathrm{ns}}$ & $0.048^{*}$ & $0.045^{*}$ & $0.765^{\text {ns }}$ \\
\hline A.B & 2 & $0.308^{\mathrm{ns}}$ & $0.349^{\mathrm{ns}}$ & $0.126^{\mathrm{ns}}$ & $0.461^{\mathrm{ns}}$ & $0.139^{\text {ns }}$ \\
\hline \multicolumn{7}{|l|}{ C. benghalensis } \\
\hline Bioassay (A) & 1 & $0.230^{\mathrm{ns}}$ & $0.196^{\mathrm{ns}}$ & $0.593^{\mathrm{ns}}$ & $0.678^{\mathrm{ns}}$ & $0.690^{\text {ns }}$ \\
\hline Root exsudates (B) & 2 & $0.001 * *$ & $0.199^{\mathrm{ns}}$ & $0.398^{\mathrm{ns}}$ & $0.008 * *$ & $0.041 *$ \\
\hline A.B & 2 & $0.403^{\mathrm{ns}}$ & $0.133^{\mathrm{ns}}$ & $0.203^{\mathrm{ns}}$ & $0.313^{\mathrm{ns}}$ & $0.493^{\mathrm{ns}}$ \\
\hline \multicolumn{7}{|l|}{ B. pilosa } \\
\hline Bioassay $(A)$ & 1 & $0.433^{\mathrm{ns}}$ & $0.365^{\mathrm{ns}}$ & $0.178^{\mathrm{ns}}$ & $0.170^{\text {ns }}$ & $0.810^{\text {ns }}$ \\
\hline Root exsudates (B) & 2 & 0.199* & $<0.001^{* * *}$ & $0.105^{\mathrm{ns}}$ & $0.012^{*}$ & $0.019 *$ \\
\hline A.B & 2 & $0.112^{\mathrm{ns}}$ & $0.300^{\mathrm{ns}}$ & $0.274^{\mathrm{ns}}$ & $0.996^{\text {ns }}$ & $0.556^{\text {ns }}$ \\
\hline \multicolumn{7}{|l|}{ D. insularis } \\
\hline Bioassay (A) & 1 & $0.891^{\mathrm{ns}}$ & $0.685^{\mathrm{ns}}$ & $0.188^{\mathrm{ns}}$ & $0.240^{\mathrm{ns}}$ & $0.270^{\mathrm{ns}}$ \\
\hline Root exsudates (B) & 2 & $0.160^{\mathrm{ns}}$ & $<0.001^{* * *}$ & $0.013^{*}$ & $0.044^{*}$ & $0.897^{\text {ns }}$ \\
\hline A.B & 2 & $0.876^{\mathrm{ns}}$ & $0.280^{\mathrm{ns}}$ & $0.854^{\mathrm{ns}}$ & $0.126^{\mathrm{ns}}$ & $0.560^{\text {ns }}$ \\
\hline \multicolumn{7}{|l|}{ C. elata } \\
\hline Bioassay (A) & 1 & $0.388^{\mathrm{ns}}$ & $0.342^{\mathrm{ns}}$ & $0.468^{\mathrm{ns}}$ & $0.474^{\mathrm{ns}}$ & $0.914^{\text {ns }}$ \\
\hline Root exsudates (B) & 2 & $0.679^{\mathrm{ns}}$ & $<0.001^{* * *}$ & $<0.001^{* * *}$ & 0.019* & $0.029 *$ \\
\hline A.B & 2 & $0.109^{\mathrm{ns}}$ & $0.333^{\mathrm{ns}}$ & $0.144^{\mathrm{ns}}$ & $0.952^{\mathrm{ns}}$ & $0.896^{\mathrm{ns}}$ \\
\hline
\end{tabular}

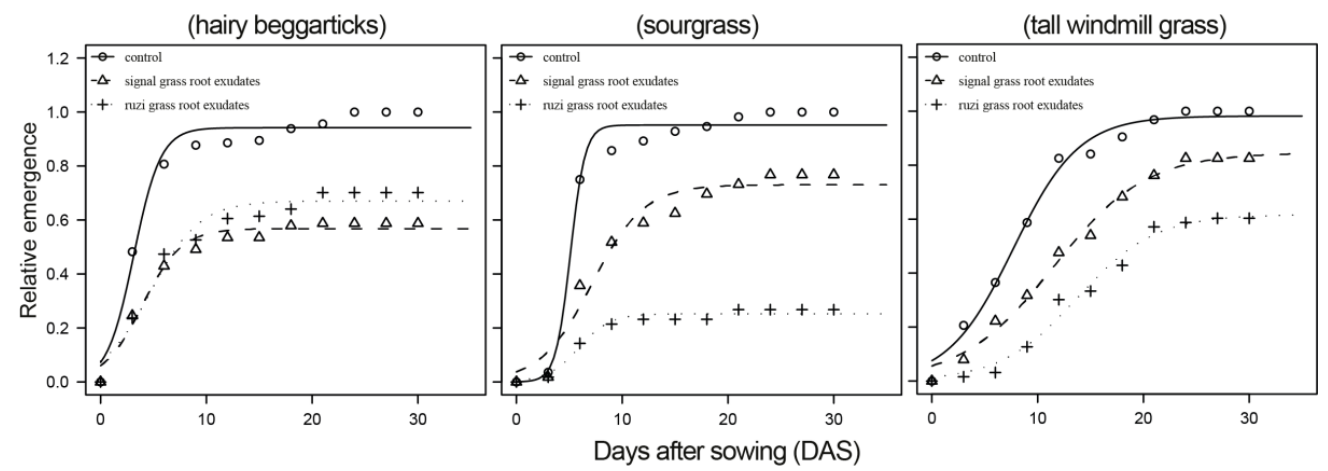

Fig 4. Relative emergence on different evaluation dates (DAS: days after sowing) of hairy beggarticks, sourgrass and tall windmill grass as a function of previously cultivated soils with Urochloa (signal grass and ruzi grass) and control (without root exudates). The relative emergence is represented by the ratio between emergence treatments emergence and the control. The parameters of the equations are in Table 2.
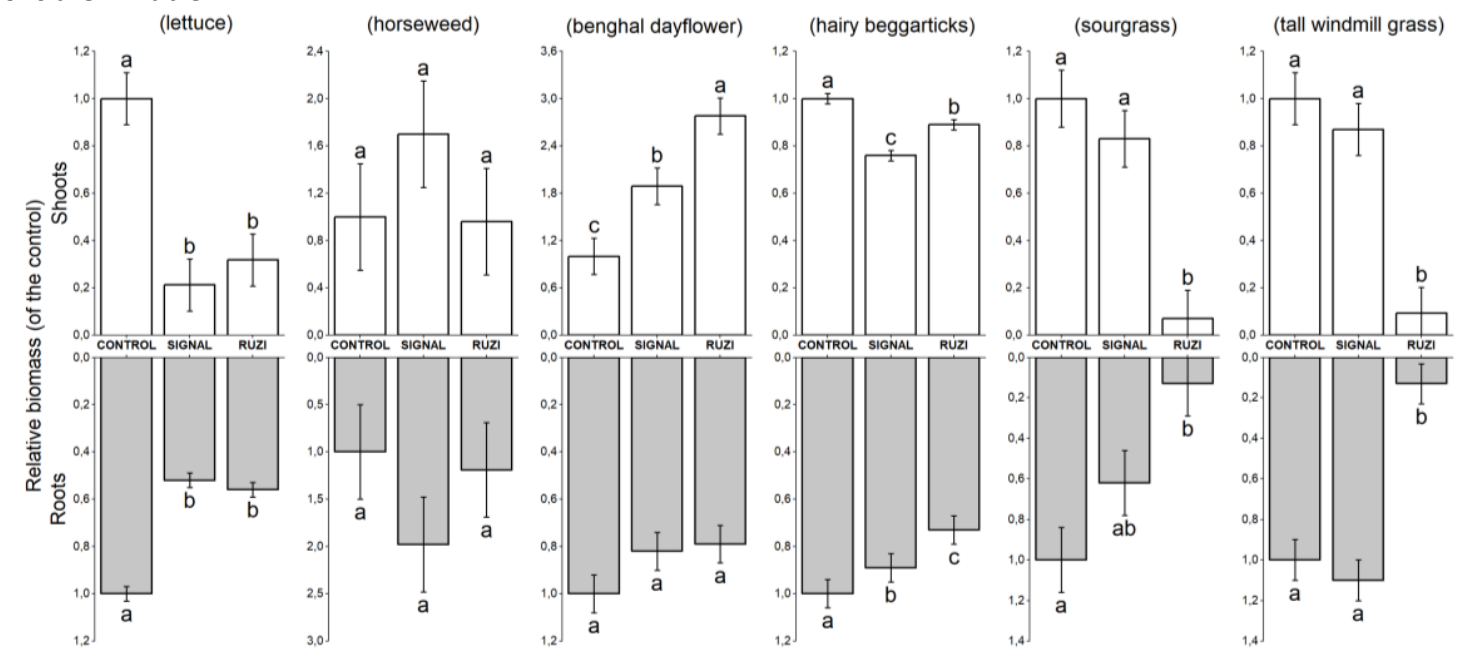

Fig 5. Relative biomass of the shoots and roots per emerged plant of lettuce (Lactuca sativa), horseweed, benghal dayflower, hairy beggarticks, sourgrass and tall windmill grass as a function of previously cultivated soils with Urochloa [signal grass (U. decumbens) and ruzi grass (U. ruziziensis)] and control (without root exudates). Means followed by the same letter within each species do not differ (Tukey's multiple comparison test; $\alpha=$ 0.05). The relative dry mass is represented by the ratio between treatments dry matter ( $\mathrm{g}$ plant ${ }^{-1}$ ) and control dry matter. CONTROL: no root exudates; SIGNAL: signal grass root exudates; RUZI: ruzi grass root exudates. \pm error bars represent the standard error of the mean. 

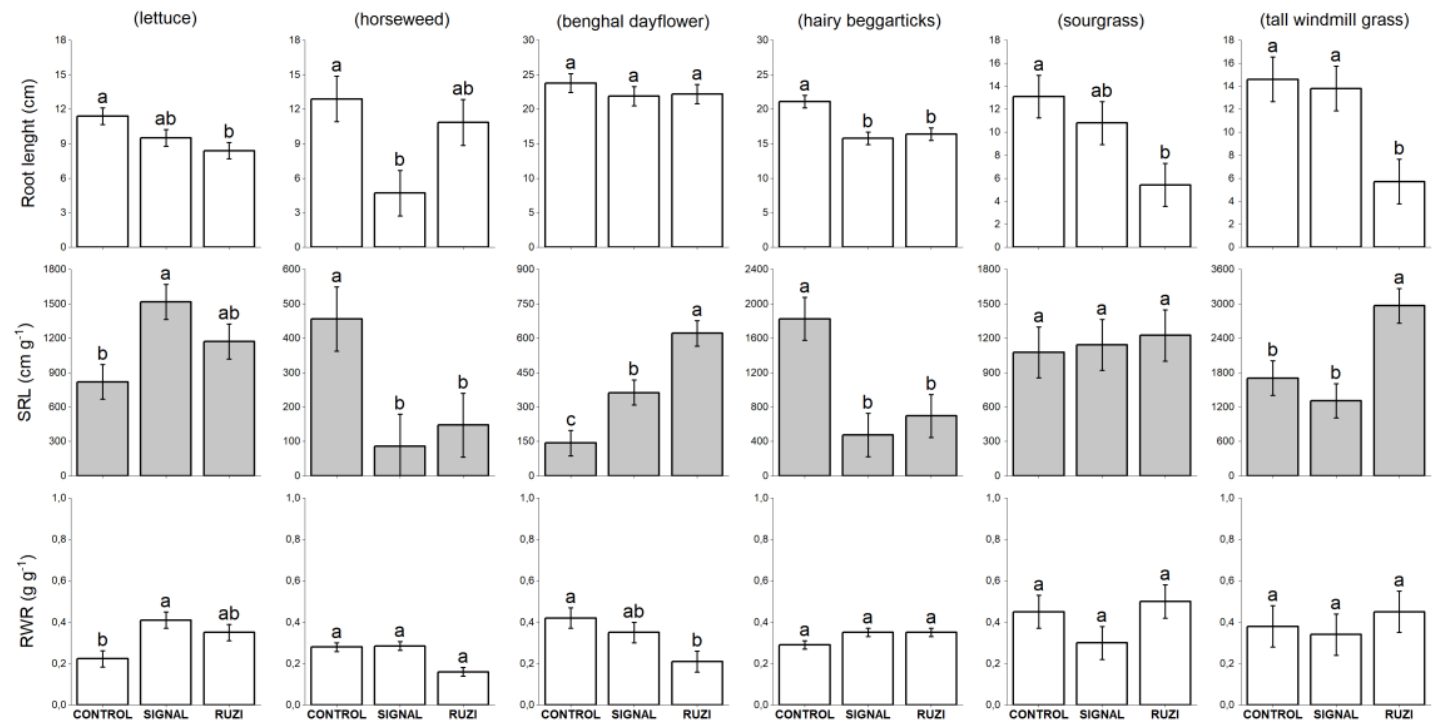

Fig 6. Root length $(\mathrm{cm})$, specific root length (SRL; root length per root dry weight, $\mathrm{cm} \mathrm{g}^{-1}$ ) and (RWR; root dry weight per plant dry weight, $\mathrm{g} \mathrm{g}^{-1}$ ) of lettuce (Lactuca sativa), horseweed, benghal dayflower, hairy beggarticks, sourgrass and tall windmill grass as a function of previously cultivated soils with Urochloa [signal grass ( $U$. decumbens) and ruzi grass ( $U$. ruziziensis)] and control (without root exudates). Means followed by the same letter within each species do not differ (Tukey's multiple comparison test; $\alpha=0.05$ ). CONTROL: no root exudates; SIGNAL: signal grass root exudates; RUZI: ruzi grass root exudates. \pm error bars represent the standard error of the mean.

There have been additional reports of growth reductions in corn (Zea mays L.), rice (Oryza sativa L.), wheat (Triticum aestivum L.), soybeans [Glycine max (L.) Merr.], beans (Phaseolus vulgaris L.), and cotton (Gossypium hirsutum L.) grown in soil in mulched with signal grass biomass (Souza et al., 2006).

Martinelli et al. (2017) have demonstrated several indications of the allelopathic effects of signal grass and ruzi grass on weeds and citrus. Low weed density values were observed on signal grass as a cover crop, suggesting that, aside from its aggressive nature, signal grass could exert allelopathic effects, either by releasing aerial volatiles or by root exudates, since as a cover crop it coexists in time and space with the crop and weeds. In addition, a lower fruit yield observed in citrus plants was proposed to be due to the following two effects: (i) the great allelopathic potential of the signal grass mulch and (ii) enhanced aggressiveness and/or allelopathic effects when the weeds were controlled by an herbicide, as when signal grass largely inhibited the citrus fruit yield.

Several secondary metabolites and various modes of release related to allelopathy have been associated with Urochloa genus plants. The phenolic compound, $p$-coumaric acid was extracted from $U$. humidicola shoots and had allelopathic activity against Desmodium adscendens (Sw.) DC., arrowleaf (Sida rhombifolia L.) and Vernonia polyanthes Less. (Souza Filho et al., 2005). The presence of the steroidal saponin, and protodioscin was described in the leaves of signal grass and $U$. brizantha, associated with the presence of allelochemicals in aqueous extracts (Barbosa et al., 2009). In a more recent study, the same steroidal saponin was also isolated from ruzi grass (Nepomuceno et al., 2017). Three allelopathically active substances were isolated from $U$. brizantha shoots and were identified as (6R,9R)-3-oxo- $a$ ionol, (6R,9S)-3-oxo- $a$-ionol and 4-ketopinoresinol, with $(6 R, 9 S)-3-0 x o-a$-ionol being the most effective inhibitor among the three (Kato-Noguchi et al., 2014). In signal grass, (6R,9S)-3-oxo- $a$-ionol was also reported to be the compound that contributes to its allelopathic abilities (Kobayashi and Kato-Noguchi, 2015).

The results of this study confirm the hypotheses raised by Martinelli et al. (2017) that signal grass and ruzi grass mulches and/or root exudates can control weeds through allelopathic effects. This study also corroborates that the "ecological mowing" management strategy can improve weed management by integrating control methods and positively using allelopathy. In addition, the action of allelopathic effects of the Urochloa on different weed species, makes detection of a unique patterns among species difficult, highlighting the inherent difficulties in allelopathy experiments. Nevertheless, it was possible to demonstrate a preventive control option for four difficult-tocontrol weeds, horseweed, benghal dayflower, sourgrass and tall windmill grass, in which there is a certain tolerance of hairy beggarticks, which may explain its high frequency in Brazilian citrus groves.

Further studies must be conducted to test allelopathic effects for additional difficult-to-control/herbicide-resistant weed species in citrus varieties and to determine which substance has the greatest effects on weeds and crops.

\section{Materials and methods}

\section{Plant material and experiments}

The allelopathic activities of the leaf extracts and roots exudates of the donor plants (signal grass and ruzi grass) were identified experimentally by their effects on the germination and development of an allelopathy indicator plant (lettuce) and five weeds (hairy beggarticks, benghal dayflower, horseweed, sourgrass and tall windmill grass). The laboratory and greenhouse bioassays were divided into two experiments: (Experiment I) the lettuce and weed germination responses to leaf extracts from signal grass and ruzi grass; and (Experiment II) the emergence and 
development of lettuce and weeds on substrates previously cultivated with signal grass and ruzi grass. The experiments treated the species as independent experiments and the bioassays performed in the spring seasons of 2017 and 2019 for lettuce, horseweed, benghal dayflower and hairy beggarticks as well as the spring seasons of 2018 and 2019 for sourgrass and tall windmill grass.

\section{Response of weed germination to aqueous extracts of Urochloa spp.}

The experimental design was completely randomised in a $2 \times$ 4 factorial scheme with four replicates of the lettuce and the weed experiments. The first factor in the scheme was donor species (signal grass or ruzi grass), and the second factor was leaf extract concentration $\left(0,75,150\right.$ and $\left.225 \mathrm{mg} \mathrm{ml}^{-1}\right)$. To begin, aqueous extracts were obtained from the leaves of signal grass and ruzi grass, which were collected from a commercial organic citrus orchard. The samples were dried at $60 \pm 3^{\circ} \mathrm{C}$ for 72 hours and hammer-milled, after which 200 $\mathrm{g}$ of each sample was weighed, mixed with $800 \mathrm{~mL}$ of distilled water and filtered to make an aqueous extract solution with a concentration of $250 \mathrm{mg} \mathrm{ml}^{-1}(25 \% \mathrm{w} / \mathrm{v})$. This solution was subsequently diluted to obtain the three test concentrations, $75 \mathrm{mg} \mathrm{ml}^{-1}(30 \% \mathrm{w} / \mathrm{v}), 150 \mathrm{mg} \mathrm{ml}^{-1}(60 \% \mathrm{w} / \mathrm{v})$ and $225 \mathrm{~g} \mathrm{ml}^{-1}(90 \% \mathrm{w} / \mathrm{v})$.

Germination was tested in Petri dishes, with fifty seeds per dish for each species, and each was considered one replicate. The Petri dishes were kept in a BOD (Biochemical Oxygen Demand)-type climatic chamber at $25^{\circ} \mathrm{C}\left( \pm 0.5^{\circ} \mathrm{C}\right.$ accuracy) with a $12 / 12 \mathrm{~h}$ photoperiod. The osmotic potential of the different solutions was analysed using the Wescor model HR-33T microvoltmeter and the $\mathrm{pH}$ was measured with a $\mathrm{pH}$ meter.

Because osmotic potential can influence allelopathy, its effects on the germination process of the weeds and lettuce were evaluated. A germination test using solutions of polyethylene glycol (PEG-6000) at predetermined osmotic potentials was set up with the same conditions used for the lettuce and weed tests in the previous bioassay (fifty seeds per Petri dish, BOD at $25^{\circ} \mathrm{C}$ and $12 / 12 \mathrm{~h}$ photoperiod). The osmotic potentials were determined as in Michel and Kaufmann (1973) to be as follows: 0.0 (control), $-0.09,-0.11$ and $-0.16 \mathrm{MPa}$ (for signal grass) or $-0.09,-0.14$ and -0.17 $\mathrm{MPa}$ (for ruzi grass) and corresponded to the osmotic potentials found in the leaf extracts at the 75, 150 and 225 $\mathrm{mg} \mathrm{ml}^{-1}$ dilution, respectively. It should also be noted that the $\mathrm{pH}$ values of the extracts from every concentration $(6.44$ \pm 0.05 ) of both Urochloa species were similar to the $\mathrm{pH}$ of the control $(6.53 \pm 0.04)$.

The germination rate was determined in four evaluations at three-day intervals $(3,6,9,12$ and 15 days after installation DAI). Seeds that emitted radicles with a size equal to or greater than $2.0 \mathrm{~mm}$ were considered as germinated. It is important to note that, to isolate the effect of the osmotic potential from the allelopathic effect, the germination values used for the analyses were adjusted according to the results of the germination tests with the PEG-6000. For each concentration of Urochloa species leaf extract, the differences in germination rate inhibition, provided by the PEG-6000 germination tests, were subtracted from the germination inhibition rate of the leaf extracts by the following formula:

Galle $=$ G leaf ext $($ Gleaf ext - GPEG $)$
Where; Galle is the relative germination rate due to allelopathy, Gleaf ext is the relative germination rate in the leaf extract bioassays, and GPEG is the relative germination $r$ ate in the PEG-6000 bioassays.

\section{Emergence and development of weeds in substrates} previously cultivated with Urochloa spp.

The treatments in Experiment II consisted of substrate in which the donor plants were grown either in (i) signal grass (U. decumbens), (ii) ruzi grass (U. ruziziensis) or (iii) without plant donor (control). The experimental design was completely randomised with four replicates. The lettuce and weeds (hairy beggarticks, benghal dayflower and horseweed, i.e. the same weeds as in Exp. I) bioassays were carried out as independent experiments.

Signal grass and ruzi grass seeds were sown (July 2017, 2018 and 2019) in $10 \mathrm{~L}$ pots containing washed sand, seven plants per species per pot, and grown in greenhouse conditions in Cordeirópolis, São Paulo State, Brazil. During this period, when the Urochloa plants were at least $30 \mathrm{~cm}$ high and in the pre-flowering stage (beginning of panicle formation; approximately 60 days after sowing), the plants were removed, and their rooting substrate was divided into individual $3 \mathrm{~L}$ pots. In each pot, 50 seeds of lettuce or weeds were sown in the Urochloa-treated substrate. The pots were irrigated daily with individualized flow drippers $\left(0.8 \mathrm{~L} \mathrm{~h}^{-1}\right)$ for two periods lasting ten minutes each. The receiver plants were grown in a soil in which the donor plant has been grown, while the control is a receiver plant in the soil with no previous donor plant. This can demonstrate allelopathy without complications from resource competition (Duke, 2015).

The number of emerged seedlings was evaluated at threeday intervals for one month, to calculate cumulative emergence. At the end of the experiment, the root length was measured, and the shoots and roots were dried $(60 \pm 3 \circ \mathrm{C} ; 72 \mathrm{~h})$ and weighed $( \pm 0.001 \mathrm{~g})$. The relationship between growth and root weight was determined, as the specific root length (SRL; root length per root dry weight, $\mathrm{cm}$ $\mathrm{g}^{-1}$ ) and root weight ratio (RWR; root dry weight per plant dry weight, $\mathrm{g} \mathrm{g}^{-1}$ ).

\section{Statistical analyses}

All data were subjected to ANOVA. The Experiment I germination data and the Experiment II emergence data were analysed by nonlinear regression (Ritz et al., 2013). A three-parameter logistic model was used (Streibig et al., 1993; Seefeldt et al., 1995):

$y=d /[1+(x / x 0) b]$

Where; $d$ is the value of the upper limit of the curve, $x$ is the response variable, $x O$ is the value that represents $50 \%$ of the variable, and $b$ is the relative slope of the curve. For this study, $d$ denotes the number of seeds that germinated and/or emerged during the experiment out of the total number of seeds sown at the beginning of the experiment (Ritz et al., 2013). All regression models were compared by ANOVA to determine which of the factors (bioassays, donor species and extract concentration) influenced the models. The fit of the regression models was evaluated by the lackof-fit $F$-test $(\alpha=0.05)$, based on the analysis of variance, demonstrating the quality of the modelling by comparing the sum of squares of the regression analysis residual with the square sums of the residual of the variance analysis (Onofri et al., 2010; Ritz et al., 2015). 
For the dry mass, root length, SRL and RWR data from Experiment II, differences among treatments were determined using Tukey's multiple comparison test $(\alpha=$ $0.05)$. All analyses were performed in $R$ software ( $v$ 3.4.3) $(R$ Development Core Team 2016). For nonlinear regressions, the drc package was used (Ritz and Streibig, 2014), and for the multiple comparison procedures, the agricolae package was used (De Mendiburu, 2014).

\section{Conclusion}

There are allelopathy effects from signal grass and ruzi grass on five of the most important weeds in Brazilian citrus groves by the following: (i) foliar allelochemicals, which show different degrees of weed control potential by germination inhibition (in order of susceptibility: benghal dayflower $>$ sourgrass $=$ tall windmill grass $=$ horseweed (with ruzi grass leaf extracts) $>$ horseweed (with signal grass leaf extracts) > hairy beggarticks) and (ii) root exudate allelochemicals, which inhibit the emergence and the root development of all five weeds and their biomass accumulation, with horseweed as an exception.

\section{Acknowledgments}

We thank to Syngenta Brazil and São Paulo State Research Foundation (FAPESP) for financial support (process 2014/21349-4), the Coordination for the Improvement of Higher Education Personnel (CAPES) and the National Council for Scientific and Technological Development (CNPq) for granted scholarships to R Martinelli and FA Azevedo, respectively.

\section{No conflicts of interest have been declared.}

\section{References}

Aerts R, Boot RGA, Van der Art PJM (1991) The relation between above-and belowground biomass allocation patterns and competitive ability. Oecologia. 87:551-559.

Alcántara-de la Cruz, R; Amaral, GS; Oliveira, GM; Rufino, LR; Azevedo, FA; Carvalho, LB; Silva, MFGF. (2020) Glyphosate resistance in Amaranthus viridis in brazilian citrus orchards. Agriculture. 10, 304.

Azevedo FA, Almeida RF, Martinelli R, Próspero AG, Licerre $\mathrm{R}$, Conceição PM, Arantes ACC, Dovis VL, Boaretto RM and Mattos Jr D (2020) No-Tillage and High-Density Planting for Tahiti acid lime grafted onto Flying dragon trifoliate orange. Frontiers in Sustainable Food Systems. 4:108.

Barbosa EG, Pivello VR \& Meirelles, S. (2008). Allelopathic evidence in Brachiaria decumbens and its potential to invade the Brazilian cerrados. Brazilian Archives of Biology and Technology. 51:825-831.

Barbosa FM, Brum, KBB, Fernandes CE, Pinto GS, Martins CF, Castro VS, Rezende KG, Riet-Correa F, HarAGUCHI M, Wysocki HLJ, Lemos RAA (2009) Variations of saponin level $\mathrm{x}$ maturation in Brachiaria brizantha leaves. In: 8th International Symposium on Poisonous Plants, 2009, João Pessoa, Paraíba. Program and Abstracts. Campina Grande, UFPB, p.13.

Batish DR, Singh HP, Kohli RK, Saxena DB, Kaur S (2002) Allelopathic effects of parthenin against two weedy species, Avena fatua and Bidens pilosa. Environmental Experimental Botany. 47:149-155.
Belz RG, Reinhardt CF, Foxcroft LC, Hurle K (2007) Residue allelopathy in Parthenium hysterophorus $L$. Does parthenin play a leading role? Crop Protection, 26:237-245.

Bhowmik PC, Bekech MM (1993) Horseweed (Conyza canadensis) seed production, emergence, and distribution in no-tillage and conventional-tillage corn (Zea mays). Agronomy Trends Agricultural Science. 1:67-71.

Carvalho WP, Carvalho GJ, Abbade Neto DO, Teixeira LGV (2012) Alelopatia de adubos verdes sobre feijoeiro comum (Phaseolus vulgaris L.) Allelopathy of green manures extracts on germination and initial growth of the lettuce. Revista Brasileira de Biociências. 10:93-86.

Coelho EMP, Galletti PA, Britta EA, Costa ACPR, Zucareli V (2019) Morphological and Biochemical Study of Bidens pilosa on the Effects of Extract of Urochloa ruziziensis. Journal of Agricultural Science. 11. 217.

De Mendiburu F (2014) Agricolae: statistical procedures for agricultural research. $R$ package version 1.

Duke SO (2015) Proving allelopathy in crop-weed interactions. Weed Science. 63:121-132

Eissenstat DM (1991) On the relationship between specific root length and the rate of root proliferation: a field study using citrus rootstocks. New Phytology. 118:63-68.

El-Gawad AMA, Mashaly IA, Ziada MEA, Deweeb MR (2015) Phytotoxicity of three Plantago species on germination and seedling growth of hairy beggarticks (Bidens pilosa L.). Egypt Journal Basic Applied Science. 2:303-309.

Ferguson JJ, Rathinasabapathi B (2003) Allelopathy: how plants suppress other plants. Florida: Ed Univ Florida.

Fritz D, Bernardi AP, Haas JS, Ascoli BM, Bordignon SAL, von Poser $\mathrm{G}$ (2007) Germination and growth inhibitory effects of Hypericum myrianthum and $H$. polyanthemum extracts on Lactuca sativa L. Brazilian Journal of Pharmacon. 17:4448.

Gomes, LJP (2016) Variabilidade de resposta de diferentes populações de Digitaria insularis e estratégias de manejo de uma população resistente. M.Sc. dissertation. Jaboticabal, SP: Universidade Estadual Paulista Júlio de Mesquita Filho. $62 \mathrm{p}$.

Heap I (2019) The International Survey of Herbicide Resistant Weeds. http://www.weedscience.org/Summary/Species.aspx Acce ssed: October 22, 2019.

Inderjit, Duke SO (2003) Ecophysiological aspects of allelopathy. Planta. 217:529-539.

Inderjit, Keating KI (1999) Allelopathy: principles, procedures, processes, and promises for biological control. Advances in Agronomy. 67:141-231.

Kato-Noguchi, H Kobayashi A, Ohno O, Kimura F, Fujii Y, Suenaga K (2014) Phytotoxic substances with allelopathic activity may be central to the strong invasive potential of Brachiaria brizantha. Journal of Plant Physiology. 17:525530.

Kobayashi A, Kato-Noguchi H (2015a) Phytotoxic substance with allelopathic activity in Brachiaria decumbens. Natural Product Communications. 10:761-763.

Martinelli R, Monquero P, Fontanetti A, Conceição $P$, Azevedo $F$ (2017) Ecological mowing: an option for sustainable weed management in young citrus orchards. Weed Technology. 31:260-268.

McCarty LB, McCauley RK, Liu H, Totten FW, Toler JE (2010) Perennial ryegrass allelopathic potential on bermudagrass germination and seedling growth. Horticultural Science. 45:1872-1875. 
Michel BE \& Kaufmann MR (1973). The osmotic potential of polyethilene glycol 6000. Plant Physiology. 51:914-916.

Monquero PA, Christoffoleti PJ, Osuna MD, De Prado RA (2004) Absorption, translocation and metabolism of glyphosate by plants tolerant and susceptible to this herbicide. Planta Daninha. 22:445-451.

Muniz FR, Cardoso MG, Pinho EVR, Vilela, M (2007) Qualidade fisiológica de sementes de milho, feijão, soja e alface na presença de tiririca. Revista Brasileira de Sementes. 29:195-204.

Nepomuceno M, Chinchilla N, Varela RM, Molinillo JM, Lacret R, Alves PL, Macias FA (2017) Chemical evidence for the effect of Urochloa ruziziensis on glyphosate-resistant soybeans. Pest Management of Science. 73:2071-2078.

Oleszek W (1987) Allelopathic effects of volatiles from some Cruciferae species on lettuce, barnyard grass and wheat growth. Plant Soil. 102:271-273.

Oliveira JR, Rios FA, Constantin J, Ishii-Iwamoto EL, Gemelli A, Martini PE (2014) Grass straw mulching to suppress emergence and early growth of weeds. Planta Daninha. 32:11-17

Onofri A, Carbonell EA, Piepho HP, Mortimer AM, Cousens RD (2010) Current statistical issues in Weed Research. Weed Research. 50:5-24.

R Development Core Team (2016) A Language and Environment for Statistical Computing. Vienna, Austria: R Foundation for Statistical Computing. http://www.Rproject.org/. Accessed: November 15, 2017.

Ritz C, Kniss AR, Streibig JC (2015) Research methods in weed science: statistics. Weed Science. 63:166-187.

Ritz C, Pipper CB, Streibig, JC (2013) Analysis of germination data from agricultural experiments. European Journal of Agronomy. 45:1-6.

Ritz C, Streibig JC (2014) drc: Analysis of Dose-Response Curve Data Version 2.3-96. http://cran.rproject.org/web/packages. Accessed: September 06, 2016.

Ronchi CP, Silva AA, Miranda GV, Ferreira LR, Terra AA (2002) Misturas de herbicidas para o controle de plantas daninhas do gênero Commelina. Planta Daninha. 20:311318.
Ryser P, Lambers H (1995) Root and leaf attributes accounting for the performance of fast-and slow-growing grasses at different nutrient supply. Plant Soil. 170:251265.

Seefeldt SS, Jensen JE, Fuerst EP (1995) Log-logistic analysis of dose-response relationships. Weed Technology. 9:218227.

Souza Filho APS, Guilhon GMSP, Santos LS (2010) Methodologies Applied in Allelopathic Activity Evaluation Studies in the Laboratory: A Critical Review. Planta Daninha. 28:689-697.

Souza Filho APS, Pereira AAG, Bayma JC (2005) Allelochemical Produced by the Forage Grass Brachiaria humidicola. Planta Daninha. 23:25-32.

Souza LS, Velini ED, Martins D, Rosolem CA (1997) The possible allelopathic effects of Brachiaria decumbens on initial development of root stock of Citrus limonia. Planta Daninha. 15:122-129.

Souza LS, Velini ED, Martins D, Rosolem CA (2006) Allelopathic Effects of Brachiaria decumbens on the Initial Development of Seven Crops. Planta Daninha. 24:657-668.

Streibig JC, Rudemo M, Jensen JE (1993) Dose-response curves and statistical models. In Streibig JC, Kudsk P (Eds.). Herbicide Bioassays 29-55. Boca Raton: CRC.

Subbarao GV, Nakahara K, Hurtado MDP, Ono H, Moreta DE, Salcedo AF, Yoshida M (2009) Evidence for biological nitrification inhibition in Brachiaria pastures. Proceedings of National Academy of Science USA. 106:17302-17307.

Voll E, Franchini JC, Da Cruz RT, Gazziero DLP, Brighenti AM, Adegas FS (2004) Chemical interactions of Brachiaria plantaginea with Commelina benghalensis and Acanthospermum hispidum in soybean cropping systems. Journal of Chemistry Ecology. 30:1467-1475.

Wakjira M, Berecha G, Bulti B (2005) Allelopathic effects of Parthenium hysterophorus extracts on seed germination and seedling growth of lettuce. Tropical Science. 45:159162. 